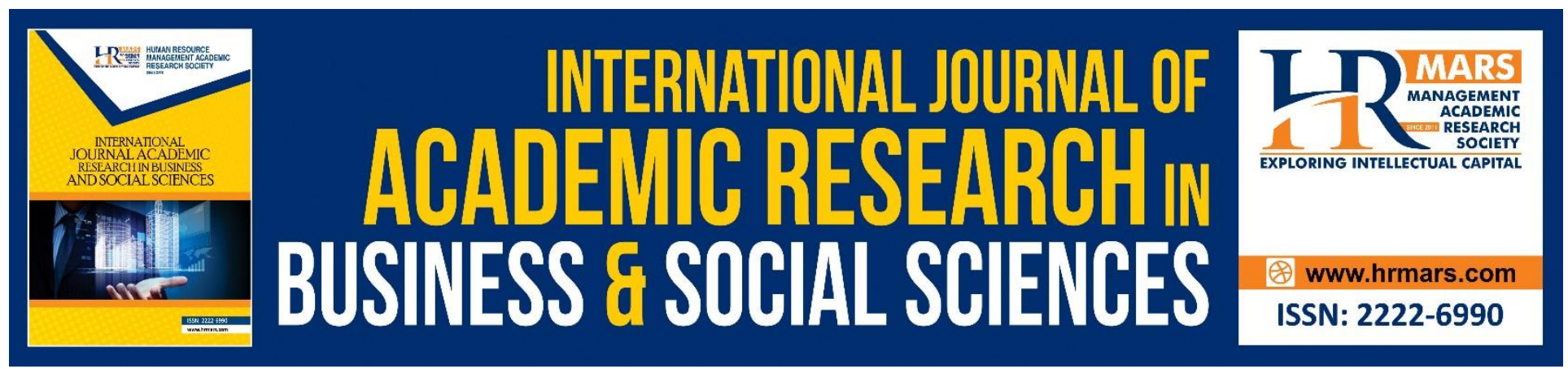

\title{
An Evaluation of Internet Financial Reporting on Specific Malaysian Economic Sectors
}

Siti Zaidah Turmin, Mohamad Noor Hisham Osman

To Link this Article: http://dx.doi.org/10.6007/IJARBSS/v10-i11/7750

DOI:10.6007/IJARBSS/v10-i11/7750

Received: 01 September 2020, Revised: 27 September 2020, Accepted: 23 October 2020

Published Online: 16 November 2020

In-Text Citation: (Turmin, \& Osman, 2020)

To Cite this Article: Turmin, S. Z., \& Osman, M. N. H. (2020). An Evaluation of Internet Financial Reporting on Specific Malaysian Economic Sectors. International Journal of Academic Research in Business and Social Sciences. 10(11), 323-346.

Copyright: (C) 2020 The Author(s)

Published by Human Resource Management Academic Research Society (www.hrmars.com)

This article is published under the Creative Commons Attribution (CC BY 4.0) license. Anyone may reproduce, distribute, translate and create derivative works of this article (for both commercial and non-commercial purposes), subject to full attribution to the original publication and authors. The full terms of this license may be seen

at: http://creativecommons.org/licences/by/4.0/legalcode

Vol. 10, No. 11, 2020, Pg. 332 - 346

http://hrmars.com/index.php/pages/detail/IJARBSS

JOURNAL HOMEPAGE

Full Terms \& Conditions of access and use can be found at http://hrmars.com/index.php/pages/detail/publication-ethics 


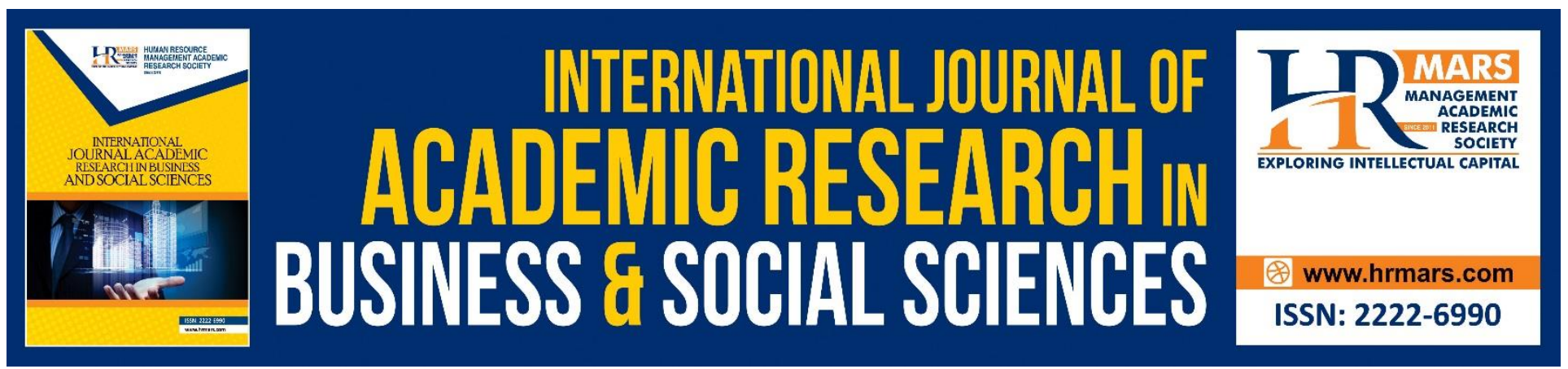

\title{
An Evaluation of Internet Financial Reporting on Specific Malaysian Economic Sectors
}

\author{
Siti Zaidah Turmin, Mohamad Noor Hisham Osman \\ Department of Accounting and Finance, School of Business and Economics, Universiti Putra \\ Malaysia, Serdang, Selangor, Malaysia \\ Email: zaidah@upm.edu.my
}

\begin{abstract}
Internet Financial Reporting (IFR) is the communication process between the corporate sector and its stakeholders, via the medium of the Internet. This study was conducted to examine the factors inspiring the extent of IFR practices by companies in specific Malaysian economic sectors. The sample consisted of fifty companies practising IFR from the sectors of plantations, trading and services, consumer products, industrial products and technology. Data was collected through the websites of the sampled companies. The results of multiple regressions have revealed that the independent variable of profitability, as measured by the return on equity, as well as the independent variable of the type of auditor, were found to positively and significantly inspire the extent of IFR practises among the sampled companies. The factors of leverage, liquidity, industry type and firm size were, however, found to be insignificant. The study has made a significant contribution towards the knowledgebase of IFR issues in the context of emerging economy countries which have previously experienced very limited study, as well as raising implications for users and auditors.
\end{abstract}

Keywords: Internet Financial Reporting, Inspiring Factors, Economic Sectors, Corporations, Malaysia.

\section{Introduction}

Internet financial reporting (IFR) is defined as the dissemination of financial statements via the corporate web, links to annual reports elsewhere on the Internet or a link to the Security and Exchange Commission's Electronic, Data Gathering, Analysis and Retrieval System (Ashbough, Johnstone and Warfield, 1999). Another definition has been offered by Poon, Li and Yu (2003), whereby IFR is described as the role of corporations in disseminating information regarding their financial performance to promote themselves to investors. IFR is seen as a contemporary, fastgrowing phenomenon, and of great magnitude in today's corporate world. It is used as a medium of communication between the corporate sector and its stakeholders, through the propagation of corporate information from businesses to shareholders, suppliers, clients and other interested parties.

The advantages of IFR include; the innovative presentation of information (Jones and Xiao, 2004), dynamic multimedia formats (Debreceny, Gray and Rahman, 2002), wider and easier access 
INTERNATIONAL JOURNAL OF ACADEMIC RESEARCH IN BUSINESS AND SOCIAL SCIENCES Vol. 10, No. 11, 2020, E-ISSN: 2222-6990 @ 2020 HRMARS

to information for larger groups of users, without selection (Ettredge, Richardson and Scholtz, 2001), creating interest for potential investors and boosting corporate images. (Ettredge et al., 2001). Besides, IFR can provide timeliness (Pratt, 1996) and more interactive information with unlimited space (Joseph, 1995) and faster and lower-cost information dissemination (Geering, Bollen and Hassink, 2003).

For developing countries, within emerging markets, which includes Malaysia, there is a need to raise capital, attract foreign investment and promote the confidence of shareholders. Moreover, expanding the global reach of the Malaysian capital market is one of the strategic objectives of Bursa Malaysia. In achieving these aims, businesses in Malaysia need to provide fair, efficient and transparent financial information. With the many advantages of IFR, as compared to traditional paper-based corporate reporting, IFR is believed to provide a way for Malaysian companies to disseminate online financial information which may attract a wider range of investors. Nevertheless, there is an issue regarding the non-standardisation of IFR practised by corporations in Malaysia, which reflects the difficulties in achieving the dissemination of corporate information, transparently, fairly and efficiently. Such non-standardisation is expected to be caused by certain company characteristics which influence the extent of their practice of IFR. Therefore, this study has been conducted to investigate the factors that induce the practice of IFR by Malaysian corporations in specific economic sectors.

\section{Literature Review}

An attempt to study the history of IFR in the business arena was made by Lymer (1999). According to Lymer (1999), several stages were involved in the continuation of this new type of reporting. Despite the age of the Internet, which now exceeds thirty years, chronological literature regarding IFR only started in 1994 with the process of re-examining accountant's functions, as well as other parties related to the accounting profession. These studies took place in the US, the UK, Australia and Canada. This literature arose from dissatisfaction and concern about the activities and regulations of business reporting. Simultaneously, this period documented a basic reconsideration of the primary accounting foundation, demand for a truly global accounting standard and the full international prominence of the International Accounting Standards Committee (IASC), as well as changes in the European Union's role relating to accounting regulation. Subsequently, the importance of information management, which was previously seen as a secondary task by business entities, was recognised as a critical activity in ensuring business success. Consequently, the issues of information technology and its influence upon accounting activities started to evolve with the Internet, as a computer-to-computer communication tool, becoming one of the said elements. Only in 1995 did business entities start to pay serious attention to this technology, following the development of the World Wide Web, or Web, as one of the Internet tools which has attracted increasing numbers of users around the world. As the years have passed by, the function of the Internet for business entities has gone beyond simply advertising and electronic commerce activities to include reporting and the dissemination of business information to users, resulting from the increasing demand for companies to be more responsible with regards to ethics and the environment.

In the UK, the earliest study examining the factors influencing internet reporting by UK companies was carried out by Craven and Marston (1999). Using a sample of 153 company websites, the study investigated the effect of two factors, namely; company size and activity sector, towards 
INTERNATIONAL JOURNAL OF ACADEMIC RESEARCH IN BUSINESS AND SOCIAL SCIENCES Vol. 10, No. 11, 2020, E-ISSN: 2222-6990 @ 2020 HRMARS

the extent of financial disclosure on corporate websites. The results of the Kruskal-Wallis test indicated that company size had a positive significant association with both website existence and the level of Internet financial disclosure. However, different results were found with regards to the activity sector. The chi-square test, which was conducted, revealed no relationship between this factor and the existence of websites and the level of financial disclosure on the sampled websites.

A study by Dutta and Bose (2007) focused on examining the extent of Internet reporting practised by Bangladeshi companies. This study used a wider sample of 268 companies listed on the Dhaka and Chittagong Stock Exchanges, which consisted of 15 sectors. Dutta and Bose (2007) measured the extent of Internet reporting based on five groups of attributes which constituted a total of 65 items, namely; financial information, corporate governance, social and environmental, investor relations and presentations. In determining the Internet reporting scores of each company, the study used a dichotomous index, whereby an item was awarded a score of 1 if it was disclosed and a score of 0 if otherwise. The results revealed that less than half of the companies (104 companies, 39\%) had websites, with companies from the banking, leasing and finance sector being the greatest in number. The Internet reporting scores of the sampled companies ranged from 1 point to 25 points with a mean of 9 points, thus, indicating a low level of Internet reporting. Besides, a medium variation was found with regards to the Internet reporting disclosure level among the companies in the study, as indicated by the standard deviation of 6.75. Subsequently, the content analysis which was conducted, showed that most of the attributes were disclosed by the companies. Specifically, nearly two-thirds of the company websites (64 websites, $61.54 \%$ ) disclosed financial information with press releases being the most frequent attribute found (44\%), followed by the past years' balance sheet and profit and loss account (28\%) and the current year's annual report (24\%). A larger number of websites were found relating to corporate governance disclosure (74 websites, $71.15 \%)$. The most common attribute found was directors' information (63\%), followed by executive officers' information (39\%) and the shareholding structure (23\%). However, only 40 websites (38\%) were found to disclose social and environmental attributes with the disclosure of donations being the top (16\%), followed by employee training and environmental policy statements (14\% for each item). As for investor relations attributes, the level of disclosure appeared to be very low with less than $10 \%$ of companies found to have most of the items. However, all of the websites were in the English language, with not a single website providing information in Bangla. In terms of presentation, a link to a press release, which was provided by 45 companies (43\%), was most commonly found, followed by annual reports in pdf format (29\%), internal search engine (28\%) and site map (27\%). Surprisingly, 15 companies (14\%) were found to provide downloadable and processable data on their websites. Thus, Dutta and Bose (2007) concluded that the Internet reporting practised by Bangladeshi listed companies was in its infancy stage, with the establishment of corporate websites for corporate reporting purposes for companies in the banking, leasing and finance sector, while other sectors were lagging far behind. Furthermore, Bangladeshi companies were mentioned by Dutta and Bose (2007) to not be using the full potential of the Internet in communicating corporate information to their stakeholders.

A study on the determinants of Internet reporting in New Zealand was conducted by Laswad, Fisher and Oyelere (2005). Laswad et al., (2005) looked at other perspectives, whereby, several characteristics of New Zealand's government authorities were examined to identify the impact of those factors upon the practice of IFR. The factors examined consisted of; political competition, local authority size, leverage, municipal wealth, press visibility and council type. The results of the 
INTERNATIONAL JOURNAL OF ACADEMIC RESEARCH IN BUSINESS AND SOCIAL SCIENCES Vol. 10, No. 11, 2020, E-ISSN: 2222-6990 @ 2020 HRMARS

multivariate regression analysis which was conducted indicated the significant positive impact of leverage, municipal wealth and press visibility against the practice of IFR in New Zealand's local authorities. Moreover, council type was also found to be a significant influence upon IFR practice, with a higher proportion of city councils engaged in IFR, as compared to regional and district councils. However, neither political competition, nor authority size, showed any relationship, and, thus, did not determine the IFR practices of New Zealand's government authorities.

Further research on the influencing factors of corporate internet reporting was conducted by Abdelsalam, Bryant and Street (2007). Their study included corporate governance factors in examining the determinants of corporate internet reporting comprehensiveness. The sample which they used comprised 110 listed companies in London. The corporate governance factors examined were; major shareholdings, directors' holdings, director independence, CEO role duality and analyst followings. Besides, the company characteristics of; size, profitability and industry type were included as control variables. Corporate internet reporting comprehensiveness, which contained 143 items, was further disaggregated into general content (19 items), credibility content ( 55 items) and usability (69 items). Consistent with other previous studies, this study applied dichotomous variables with a score of 1 for the existence of items in the websites, and a score of 0 for otherwise. The results of the OLS regression which was conducted indicated that major shareholdings had no significant influence on any of the corporate internet reporting measures (comprehensiveness, general content, credibility and usability). However, directors' holdings were found to be significant but negatively associated with all of the corporate internet reporting measures. Furthermore, a positive significant relationship was found concerning the relationship between analyst followings and all of the corporate internet reporting measures. Furthermore, only corporate internet reporting comprehensiveness and general content appeared to be positively and significantly influenced by director independence. The dual role of the CEO was found to be significant against credibility content, but with an inverse relationship. The results for the control variables revealed a positive significant impact of the manufacturing industry on corporate internet reporting comprehensiveness and general content but a negative significant impact for high growth industry on general content and usability. Besides, company size was also found to be positively and significantly associated with credibility content. However, profitability was found to be insignificant against all of the corporate internet reporting measures.

Further to Abdelsalam et al., (2007), the impact of corporate governance attributes on the corporate internet reporting practices of Egyptian companies were investigated by Samaha, Dahawy and Abdel-Meguid (2012). Specifically, Samaha et al., (2012) focused on the influence of ownership structures and the boards of directors towards the propensity and comprehensiveness of corporate internet reporting practices among the largest 100 companies listed on the Egyptian Stock Exchange. The propensity of corporate internet reporting practices, which referred to the adoption of corporate internet reporting, was measured through a dummy variable which was set at 1 for companies with accessible corporate websites and 0 otherwise. Corporate internet reporting comprehensiveness was operationalised by a checklist of 67 items of content and 20 items of presentation. Regarding corporate governance attributes, the ownership structure was proxied by; free float, managerial ownership and government ownership, while the structure of the board of directors was measured by; board size, board independence and CEO-chair duality. The result of the binary logistic regression which was carried out indicated that companies with greater ownership dispersion, managerial ownership, governmental ownership and board independence were more likely to adopt corporate 
INTERNATIONAL JOURNAL OF ACADEMIC RESEARCH IN BUSINESS AND SOCIAL SCIENCES Vol. 10, No. 11, 2020, E-ISSN: 2222-6990 @ 2020 HRMARS

internet reporting. As for corporate internet reporting comprehensiveness, the result of the seemingly unrelated regression revealed that companies with greater ownership dispersion, governmental ownership and board independence were more likely to have more comprehensive corporate internet reporting.

Other than looking at the determinants of corporate internet reporting, Sia, Brahmana and Memarista (2018) organised a study to investigate the impact of corporate internet reporting upon the performance of 583 non-financial listed corporations in Malaysia. Besides corporate internet reporting, other factors tested were; size, leverage and the growth of the companies. In measuring the level of corporate internet reporting disclosure for each company being investigated, the actual scores of each company were divided by the maximum possible scores from a total of 36 items. These items consisted of 12 disclosure items and 24 content items. Content analysis was used to measure corporate internet reporting, whilst a regression model was used to investigate the results of independent variables upon firms' performance. The findings of the study revealed that performance, which was represented by Tobin's $Q$, had a positive and significant relationship with corporate internet reporting at the 1 per cent level of confidence. Growth also revealed a positive and significant impact on companies' performance. On the contrary, leverage was found to have a negative but significant influence upon the performance of companies, whilst size did not show a significant effect upon companies' performance. Therefore, the results showed that the greater the level of corporate internet reporting which was being practised by the companies, the higher would be the performance of the companies.

Despite focusing on the extent and determinants of corporate internet reporting, an effort was carried out by Hermawan, Biduri, Hariyanto and Ningdiyah (2019) to look at the relationship between corporate governance factors and the quality of corporate internet reporting practised by pharmaceutical companies in Indonesia and Malaysia over the period between 2012 to 2016. Corporate governance factors consisted of profitability, liquidity, leverage, size and the age of the companies, while the quality of corporate internet reporting was operationalised through the timeliness of information disclosed through corporate internet reporting. The data were analysed using the statistical method of logistic regression. The study found that the timeliness of the information presented through the corporate internet reporting practised by those pharmaceutical companies in Indonesia was better than those in Malaysia. Thus, stakeholders might be more satisfied and rely more on Indonesian pharmaceutical companies, as compared to those in Malaysia. Furthermore, liquidity and leverage revealed a significant and positive relationship with the corporate internet reporting quality of Indonesian companies, while for Malaysian companies, profitability was the only significant factor that positively influenced corporate internet reporting quality.

Another corporate internet reporting study, which looked into the corporate governance factor, was conducted by Bananuka, Night, Ngoma and Najjemba (2019). The study focused on the relationship between board role performance, as well as isomorphic forces and internet financial reporting, on a sample of 53 financial service companies in Uganda. Board role performance was categorised under three different dimensions, namely; control, strategic and service roles. While isomorphic forces involved; mimetic, coercive and normative forces. Questionnaires were distributed to the chief internal auditors and chief finance officers of the companies. Data were analysed using the statistical method of an ordinary least squares multiple regression. The findings of the study indicated that board role performance, under the dimensions of control and strategic role, as well as coercive isomorphic forces were positively and significantly associated with the practice of internet 
financial reporting by those companies investigated. Nevertheless, board role performance was found to be insignificant towards internet financial reporting in the presence of isomorphic forces.

Apart from the significant number of studies on the type and extent of corporate internet reporting, as well as its determinants, there have also been attempts by a few researchers to study the attitudes and preferences of corporate internet reporting. Generally, the attitudes and preferences of corporate internet reporting have been investigated, based on both the supply and demand sides of the information. Research by Beattie and Pratt (2003) was among the earliest studies examining this issue, whereby, their study aimed to examine the attitudes and preferences of various user groups against Internet business reporting. By using postal questionnaires, the study examined the views of 500 individuals from groups of expert and non-expert users in the UK with regards to the frequency of using the Internet, the desirability of different kinds of information provided by the Internet, the usefulness of different forms of navigation, as well as search aids and the portability of information in different formats. The group of expert users consisted of investment analysts, fund managers and corporate lenders, while private shareholders, finance directors and audit partners were considered as non-expert users. Generally, the study found that more than half of the respondents (60\%) used the Internet almost daily, with expert users being the most frequent users and private shareholders as the least frequent expert users. Besides, the study unveiled the preference of users for many possible expansions of additional information on corporate websites. Furthermore, all of the groups of users perceived navigation and search aids to be useful to them. Beattie and Pratt (2003) found no significant difference with regards to the views of the user groups concerning Internet reporting, thus, possibly reflecting no need for future research to consider the needs of each group for Internet reporting separately.

\section{Research Methodology}

In this study, the extent of IFR acted as the dependent variable. Systematic random sampling was used in selecting companies to be a representative sample of the study. This is due to the advantages of simplicity and flexibility of drawing the sample of study offered by this technique (Davis, 1999 and Cooper and Schindler, 2008). The total sample for the study was 50 companies, which consisted of five sectors under the main market of Bursa Malaysia, namely; plantations, trading and services, consumer products, industrial products and technology. These five sectors were selected due to the role and significance of those sectors in developing the Malaysian economy. The plantation sector plays an important role in producing agricultural products for national consumption. The sector is seen as the backbone of the Malaysian economy, due to the significance of the sector in providing a major source of employment for people, especially those from rural areas (Rozhan, 2015). In boosting the development of the agro-based sector, the plantation sector is supported by the industrial sector through the capabilities of downstream activities offered by the sector, such as product processing, packaging and distribution. The industrial sector contributes almost 80 per cent of Malaysia's overall exports, whilst the service sector employs the majority of the Malaysian population and accounts for 53 per cent of the GDP (Nordea Trade Portal, 2020). As for the technology sector, this sector plays a role in assisting other Malaysian business sectors in the utilisation and development of research and development and ICT adoption.

In examining the extent of IFR practised by listed companies in Malaysia, an IFR index was used. Lybaert (2000) mentioned that the disclosure index could be used to gain insight into the level of website disclosure. Using a previously tested checklist is said to improve the validity of the checklist 
INTERNATIONAL JOURNAL OF ACADEMIC RESEARCH IN BUSINESS AND SOCIAL SCIENCES Vol. 10, No. 11, 2020, E-ISSN: 2222-6990 @ 2020 HRMARS

in the current study (Chan and Wickramasinghe, 2006). Therefore, the development of the IFR index used in the study was based on a review of the study by Pirchegger and Wagenhofer (1999) with some modification. A total of 23 IFR items were used in the IFR index which was developed, consisting of items of both content and presentation. The study investigated the types of information disseminated through corporate websites, as well as how the information was presented and the options of technology used to create a user-friendly corporate website. Data were collected by examining the extent of the IFR practices for each sampled company website for the presence of each of the 23 measurement items, based on an unweighted index. An unweighted index is a technique, whereby the number of items disclosed by companies is examined, without considering the perception of the importance of the items by specific users (Chow and Wong-Boren, 1987). This study applied a dichotomous score of 0 or 1 , whereby a score of 1 was assigned for every IFR item if it was disclosed or practised by the company and a score of 0 was assigned otherwise. For each company, the total score of the IFR extent was measured by using a formula of the actual company's score divided by the total IFR attributes, which was adopted from Wallace and Naser (1995), Bhuiyan, Biswas and Chowdhury (2007) and Aly, Simon and Hussainey (2010). A detailed list of the items in the IFR index can be seen in Table 1.

\section{Table 1}

List of the IFR index

\begin{tabular}{|c|c|c|}
\hline Code & Content Attributes & Explanation \\
\hline $\mathrm{C} 1$ & Annual report & 1 if the annual report is available; 0 if otherwise \\
\hline $\mathrm{C} 2$ & Share price history & $\begin{array}{l}1 \text { if the website provides historical stock prices; } 0 \text { if } \\
\text { otherwise. }\end{array}$ \\
\hline C3 & Analyst forecast & $\begin{array}{l}1 \text { if the current analyst forecast or link to a current } \\
\text { analyst forecast is available on the website; } 0 \text { if } \\
\text { otherwise. }\end{array}$ \\
\hline C4 & Current selling price & $\begin{array}{l}1 \text { if the website provides a same-day stock price; } 0 \text { if } \\
\text { otherwise }\end{array}$ \\
\hline C5 & $\begin{array}{l}\text { Current press release or } \\
\text { news }\end{array}$ & $\begin{array}{l}1 \text { if the website provides current press releases of the } \\
\text { company; } 0 \text { if otherwise. }\end{array}$ \\
\hline C6 & $\begin{array}{l}\text { Social responsibility } \\
\text { disclosure }\end{array}$ & $\begin{array}{l}1 \text { if specific social responsibility news or a special } \\
\text { page on social responsibility disclosure exists in the } \\
\text { website; } 0 \text { if otherwise }\end{array}$ \\
\hline $\mathrm{C7}$ & Other languages & $\begin{array}{l}1 \text { if the website can be read in other languages; } 0 \text { if } \\
\text { otherwise. }\end{array}$ \\
\hline $\mathrm{C} 8$ & Email to investor relations & $\begin{array}{l}1 \text { if the website provides a direct e-mail contact to } \\
\text { the investor relations officer/department; } 0 \text { if } \\
\text { otherwise. } \\
\text { Not accepted if it is a general e-mail address outside } \\
\text { of the investor relations page. }\end{array}$ \\
\hline
\end{tabular}


INTERNATIONAL JOURNAL OF ACADEMIC RESEARCH IN BUSINESS AND SOCIAL SCIENCES Vol. 10, No. 11, 2020, E-ISSN: $2222-6990$ @ 2020 HRMARS

\begin{tabular}{|c|c|c|}
\hline C9 & Contact detail & $\begin{array}{l}1 \text { if the telephone number of the investor relations } \\
\text { officer/department is provided on the corporate } \\
\text { website; } 0 \text { if otherwise. }\end{array}$ \\
\hline C10 & $\begin{array}{l}\text { Frequently asked } \\
\text { questions }\end{array}$ & $\begin{array}{l}1 \text { if the FAQ is available on the website; } 0 \text { if } \\
\text { otherwise. }\end{array}$ \\
\hline Code & Presentation Attributes & Explanation \\
\hline P1 & Mailing list & $\begin{array}{l}1 \text { if the corporate website provides the postal } \\
\text { address to the investor relations officer/department; } \\
0 \text { if otherwise. }\end{array}$ \\
\hline P2 & $\begin{array}{l}\text { Loading time of the } \\
\text { website }<10 \text { seconds }\end{array}$ & $\begin{array}{l}1 \text { if the loading time of the website is less than } 10 \\
\text { seconds; } 0 \text { if otherwise. }\end{array}$ \\
\hline P3 & $\begin{array}{l}\text { Hyperlink inside the } \\
\text { annual report }\end{array}$ & $\begin{array}{l}1 \text { if there is a hyperlink inside the annual report; } 0 \text { if } \\
\text { otherwise. }\end{array}$ \\
\hline P4 & $\begin{array}{l}\text { Financial data in a } \\
\text { processable format }\end{array}$ & $\begin{array}{l}1 \text { if financial data can be processed in a spreadsheet; } \\
0 \text { if otherwise. }\end{array}$ \\
\hline P5 & $\begin{array}{l}\text { Annual report in pdf } \\
\text { format }\end{array}$ & $\begin{array}{l}1 \text { if the annual report in pdf format is available on the } \\
\text { website; } 0 \text { if otherwise. }\end{array}$ \\
\hline P6 & $\begin{array}{l}\text { Annual report in HTML } \\
\text { format }\end{array}$ & $\begin{array}{l}1 \text { if the annual report in } \mathrm{Html} \text { format is available on } \\
\text { the website; } 0 \text { if otherwise. }\end{array}$ \\
\hline P7 & $\begin{array}{l}\text { Direct email hyperlink to } \\
\text { investor relations }\end{array}$ & $\begin{array}{l}1 \text { if there is a direct email hyperlink to the investor } \\
\text { relations department; } 0 \text { if otherwise. }\end{array}$ \\
\hline P8 & Sound effect & $\begin{array}{l}1 \text { if there is a sound effect on the website; } 0 \text { if } \\
\text { otherwise. }\end{array}$ \\
\hline P9 & Video files & $\begin{array}{l}1 \text { if the website provides any video files; } 0 \text { if } \\
\text { otherwise. }\end{array}$ \\
\hline P10 & Site map & $\begin{array}{l}1 \text { if a site map is provided on the website; } 0 \text { if } \\
\text { otherwise. }\end{array}$ \\
\hline P11 & Pull-down menu & $\begin{array}{l}1 \text { if a pull-down menu is provided on the website; } 0 \text { if } \\
\text { otherwise. }\end{array}$ \\
\hline P12 & Internal search engine & $\begin{array}{l}1 \text { if an internal search engine is available on the } \\
\text { website; } 0 \text { otherwise. }\end{array}$ \\
\hline P13 & Graphic images & $\begin{array}{l}1 \text { if there are any graphic images provided on the } \\
\text { website; } 0 \text { if otherwise. }\end{array}$ \\
\hline
\end{tabular}

As for the independent variables, the company characteristics examined were; firm size, profitability, leverage, liquidity, industry type and type of auditor. Details of the operationalisation of the independent variables are presented in Table 2. Data were collected from the annual reports of the companies and were analysed using the statistical method of multiple regression. The study developed the following regression model:

$Y=\alpha+\beta_{1}\left[\right.$ SIZE-ASSET] $+\beta_{2}$ [SIZE-SALES] $+\beta_{3}[$ PROFIT- ROA $]+\beta_{4}[$ PROFIT- ROE $]+\beta_{5}\left[\right.$ LEV] $+\beta_{6-10}[$ [IND-

TYPE $]+\beta_{11}[$ AUDIT $]+\beta_{12}[$ LIQUID $]+\mu$

Where;

$\mathrm{Y}=$ level of IFR practised by companies 
INTERNATIONAL JOURNAL OF ACADEMIC RESEARCH IN BUSINESS AND SOCIAL SCIENCES Vol. 10, No. 11, 2020, E-ISSN: 2222-6990 @ 2020 HRMARS

$\alpha=$ the constant of the equation

SIZE-ASSET = total asset of the company

SIZE-SALES $=$ total sales of the company

PROFIT-ROA $=$ return on assets of the company

PROFIT-ROE= return on equity of the company

$\mathrm{LEV}=$ leverage of the company

LIQUID= liquidity of the company

IND-TYPE= activity sector

AUDIT= auditor type

$\mu=$ error term

Table 2

Operationalisation of the Independent Variables

\begin{tabular}{|l|l|}
\hline Independent Variable & Operationalisation \\
\hline Firm size & $\begin{array}{l}\text { a. Total asset } \\
\text { b. Total sales }\end{array}$ \\
\hline Profitability & $\begin{array}{l}\text { a. ROA } \\
\text { b. ROE }\end{array}$ \\
\hline Leverage & Total debt/Total equity \\
\hline Liquidity & Current asset/current liability \\
\hline Industry type & $\begin{array}{l}\text { Consumer product, plantation, trading and services, } \\
\text { industrial products, technology }\end{array}$ \\
\hline Type of auditor & Big four and non-big four \\
\hline
\end{tabular}

\section{Findings}

The results of the multiple regression model showed that profitability, as measured by the ROE and type of auditor, was positively and statistically significant at $p=0.008$ and $p=0.004$, respectively. This revealed that an increase in profitability through equity would contribute to an increase in the extent of IFR. Furthermore, companies being audited by larger audit firms (big four) tended to have a higher level of IFR practice. Other factors (firm size, leverage, liquidity and industry type) were found to be not statistically significant. This meant that the extent of IFR for those companies was not influenced by these factors. Details of the findings can be seen in Table 3. Therefore, the results showed that profitability, as measured by the ROE and type of auditors, were important in inducing the extent of IFR practised by the companies being investigated.

The results of the study can be interpreted in several ways. First, companies that have better profitability, in terms of return on equity, will tend to disclose more financial information, as compared to companies with poor profitability, when delivering good news about their business to the market (Lev and Penman, 1990). Besides, they will disclose more information to segregate themselves from companies with lower performance (Marston and Polei, 2004). Furthermore, by disclosing more information, companies with better performance can avoid the negative perception of hiding bad news among their stakeholders (Verrechia, 1983). When looking at the results, the higher the companies' return on equity, the more the companies will practice IFR to disseminate information on their profitability to their stakeholders. IFR with its advantage of providing faster tools for disseminating information to a wider group of stakeholders can be used by companies to 
INTERNATIONAL JOURNAL OF ACADEMIC RESEARCH IN BUSINESS AND SOCIAL SCIENCES Vol. 10, No. 11, 2020, E-ISSN: 2222-6990 @ 2020 HRMARS

reflect their ability in gaining returns and profits. This contributes to the finding of a positive and significant relationship between the profitability of companies and the extent of IFR their practices.

Second, concerning the result of auditor type, the big 4 audit firms tend to have a higher level of audit quality, as compared to non-big 4 audit firms. They will also encourage their clients to disclose more comprehensive financial information (DeAngelo, 1981). Therefore, companies being audited by the big 4 audit firms are expected to disclose more comprehensive financial information. Besides, the level of information disclosed by companies is a signal of the audit quality by the audit firms (Inchausti, 1997). The reputation of the big 4 audit firms will diminish with their association with companies with a low level of disclosure. On the contrary, a high level of disclosure by companies will reflect the good quality of the big 4 audit firms. Therefore, companies audited by the big 4 audit firms will tend to have a higher level of financial disclosure, and this includes financial disclosure by companies through the Internet. This contributes to the positive and significant result of the relationship between the type of auditor and the extend of IFR practised by the companies being investigated.

The results revealed that the value of the adjusted $R^{2}$ was 0.229 , indicating that the regression model could explain nearly 23 per cent of the association between the level of IFR practised by the sampled companies and its determinants. Besides, the $F$ value was 2.213 with a significance level of 0.032 , which indicated that the overall regression model was significant. Based on the results of the regression model, it can be summarised that profitability and auditor type were two factors that significantly influenced the IFR practised of the companies being investigated. However, the IFR practised in the study was not affected by the factors of firm size, leverage, liquidity and type of industry. Based on the results, the equation of the regression model was specified as IFR $=0.537+$ $0.005(\mathrm{ROE})+0.092$ (auditor) $+\varepsilon$. Details of the results can be seen in Table 3 . 
INTERNATIONAL JOURNAL OF ACADEMIC RESEARCH IN BUSINESS AND SOCIAL SCIENCES Vol. 10, No. 11, 2020, E-ISSN: 2222-6990 @ 2020 HRMARS

Table 3

Results of Multiple Regression

\begin{tabular}{|c|c|c|c|c|c|}
\hline $\begin{array}{c}\text { Independent } \\
\text { Variable }\end{array}$ & $\begin{array}{c}\text { Non- } \\
\text { standard } \\
\text { Coefficient }\end{array}$ & Std. Error & t-Statistic & Sig.T & VIF \\
\hline Constant & 0.537 & 0.099 & 5.442 & 0.000 & \\
\hline Size-asset & -1.402 & 0.000 & -0.090 & -0.928 & 8.477 \\
\hline Size-sales & -1.143 & 0.000 & -0.469 & 0.642 & 8.819 \\
\hline Profit-ROA & -0.150 & 0.137 & -1.090 & 0.283 & 1.702 \\
\hline Profit-ROE & 0.005 & 0.002 & 2.784 & 0.008 & 1.199 \\
\hline leverage & 0.045 & 0.072 & 0.618 & 0.540 & 1.909 \\
\hline liquidity & 0.000 & 0.001 & 0.203 & 0.840 & 1.644 \\
\hline auditor & 0.092 & 0.029 & 3.118 & 0.004 & 1.447 \\
\hline consumer & 0.045 & 0.098 & 0.454 & 0.652 & 11.000 \\
\hline plantation & -0.068 & 0.100 & -0.677 & 0.503 & 11.385 \\
\hline trading & 0.022 & 0.089 & 0.248 & 0.805 & 9.078 \\
\hline industrial & -0.052 & 0.089 & -0.578 & 0.567 & 9.788 \\
\hline technology & -0.008 & 0.097 & -0.080 & 0.937 & 10.664 \\
\hline \multicolumn{6}{|c|}{ Dependent variable: Overall IFR score } \\
\hline \multicolumn{2}{|c|}{$\begin{array}{l}\text { Explanation of the model: } \\
\mathrm{R}^{2}=0.418 \\
\text { Adjusted } \mathrm{R}^{2}=0.229\end{array}$} & \multicolumn{2}{|c|}{$\begin{array}{l}\text { Significance of the model: } \\
\mathrm{F} \text { value }=2.213 \\
\text { Significance }=0.032\end{array}$} & & \\
\hline
\end{tabular}

\section{Conclusion}

This study was conducted to investigate factors inspiring the extent of IFR practised by companies in specific Malaysian economic sectors. Specifically, the study examined the significance of six company characteristics, namely firm size, profitability, leverage, liquidity, industry type and type of auditor upon the extent of IFR practised by 50 listed Malaysian companies from specific economic sectors. The findings of the study revealed, through the statistical method of multiple regression, that the profitability of the sampled firms and the type of auditor were positively significant in influencing the extent of IFR practised by those companies. Companies with high profitability as well as companies being audited by the big four audit firms tended to show a higher extent of IFR practice, as compared to companies with low liquidity and companies audited by non-big four audit firms. On the other hand, four other factors investigated revealed insignificant results.

The findings of the study contribute in several ways. First, the result is useful to various stakeholder groups in gaining a better understanding of the contributing factors of IFR. As the study found that the ROE of companies had a positive significant influence towards the extent of the companies' IFR practises, the results suggested that companies with high profitability in terms of their return on equity would have better IFR practises. Furthermore, companies that were audited by the big four audit firms would tend to have a higher level of IFR practice, probably to fulfil the expected level of financial disclosure required by those audit firms. Therefore, stakeholders who are interested to invest in those companies can access corporate information through the medium of IFR provided 
INTERNATIONAL JOURNAL OF ACADEMIC RESEARCH IN BUSINESS AND SOCIAL SCIENCES Vol. 10, No. 11, 2020, E-ISSN: 2222-6990 @ 2020 HRMARS

by companies. Second, the study was conducted from the perspective of Malaysia. Thus, the findings of the study might contribute to the knowledgebase by adding to the existing literature regarding IFR in developing and emerging economy countries. Furthermore, it is hoped that the experiences of listed corporations in Malaysia when implementing IFR can assist other developing countries around the world by elucidating and simplifying IFR problems, as was mentioned by Wallace (1988). As this study focused on the characteristics of listed companies and its effect on their practice of IFR, the results of the study might be of interest to other countries in the world that are facing a similar issue.

When considering future research in the same field, this study can provide some suggestions. Future research might consider using a larger sample of corporations, as well as focusing on the comparison of IFR practices between Malaysia and other countries to gain a broader view of IFR practices by business corporations. Also, as IFR is used by business entities as a new medium for disseminating business information as well as for communication between firms and stakeholders, an initiative could be carried out in future research to investigate the IFR practices among unlisted corporations and its effect on the performance of those corporations. Besides, future research should implement a stronger IFR analytical model which may include other potential factors that might influence IFR practices by corporations.

\section{References}

Abdelsalam, O. H., Bryant, S. M., and Street, D. L. (2007). An Examination of the Comprehensiveness of Corporate Internet Reporting Provided by London-listed Companies. Journal of International Accounting Research, 6 (2), 1-33.

Aly, D., Simon, J., and Hussainey, K. (2010). Determinants of corporate internet reporting: evidence from Egypt. Managerial Auditing Journal, 25 (2), 182-202.

Ashbough, H., Johnstone, K. M., and Warfield, T. D. (1999). Corporate Reporting on the Internet. Accounting Horizons, 13(3), 241-257.

Bananuka, J., Night, S., Ngoma, M., and Nujjemba, G. M. (2019). Internet financial reporting adoption. Exploring the influence of board role performance and isomorphic forces. Journal of Economics, Finance and Administrative Science, 24 (48), 266-287.

Beattie, V., and Pratt, K. (2003). Issues concerning web-based business reporting: an analysis of the views of interested parties. The British Accounting Review, 35, 155-187.

Bhuiyan, M. H. U., Biswas, P. K., and Chowdhury, S. P. (2007). Corporate Internet Reporting Practice in Developing Economies: Evidence from Bangladesh. Cost and Management, 35(5), 1-17.

Chan, W. C., and Wickramasinghe, N. (2006). Using the internet for financial disclosures: the Australian experience. International Journal of Electronic Finance, 1(1), 118-150.

Chow, C. W., and Wong-Boren, A. (1987). Voluntary Financial Disclosure by Mexican Corporations. The Accounting Review, 62(3), 533-541.

Cooper, D. R., and Schindler, P. S. (2008). Business Research Methods. (10 ${ }^{\text {th }}$ Edn.). New York: McGrawHill.

Craven, B. M., and Marston, C. L. (1999). Financial reporting on the Internet by leading UK companies. The European Accounting Review, 8(2), 321-333.

Davis, D. (1999). Business Research for Decision Making. (5 $5^{\text {th }}$ edn.). Duxbury: Thomson Learning.

De Angelo, L. E. (1981). Auditor size and audit quality. Journal of Accounting and Economics, 3, 183 199. 
INTERNATIONAL JOURNAL OF ACADEMIC RESEARCH IN BUSINESS AND SOCIAL SCIENCES Vol. 10, No. 11, 2020, E-ISSN: 2222-6990 @ 2020 HRMARS

Debreceny, R., Gray, G. L., and Rahman, A. (2002). The determinants of Internet financial reporting. Journal of Accounting and Public Policy, 21(4-5), 371-394.

Dutta, P., and Bose, S. (2007). Web-based Corporate Reporting in Bangladesh: An Exploratory Study. The Cost and Management, 35(6), 29-45.

Ettredge, M., Richardson, V. J., and Scholtz, S. (2001). The presentation of financial information at corporate Web sites. International Journal of Accounting Information Systems, 2 (3), 149168.

Geerings, J., Bollen, L. H. H., and Hassink, H. E. D. (2003). Investor relations on the Internet: a survey of the Euronext zone. The European Accounting Review, 12(3), 567-579.

Hermawan, S., Biduri, S., Hariyanto, W., and Ningdiyah, E. W. (2019). Kualitas Corporate Internet Reporting di Indonesia dan Malaysia. Jurnal Akuntansi Multiparadigma, 10(1), 176-187.

Inchausti, B. G. (1997). The influence of company characteristics and accounting regulation on information disclosed by Spanish firms. The European Accounting Review, 6(1), 45-68.

Jones, M. J., and Xiao, J. Z. (2004). Financial reporting on the Internet by 2010: a consensus view. Accounting Forum, 28(3), 237-263.

Joseph, M. (1995). How Much to Reveal Online. CFO, 11,12.

Laswad, F., Fisher, R., and Oyelere, P. (2005). Determinants of voluntary Internet financial reporting by local government authorities. Journal of Accounting and Public Policy, 24, 101-121.

Lev, B., and Penman, S. H. (1990). Voluntary Forecast Disclosure, Nondisclosure, and Stock Prices. Journal of Accounting Research, 28(1), 49-76.

Lybaert, N. (2002). On-Line Financial Reporting. An Analysis of the Dutch Listed Firms. The International Journal of Digital Accounting Research, 2(4), 195-234.

Lymer, A. (1999). The Internet and the future of corporate reporting in Europe. The European Accounting Review, 8(2), 289-301.

Marston, C., and Polei, A. (2004). Corporate reporting on the Internet by German companies. International Journal of Accounting Information Systems, 5(3), 285-311.

Nordea Trade Portal. (2020). The economic context of Malaysia. https://www.nordeatrade.com/fi/explore-new-market/malaysia/economical-context

Pirchegger, B., and Wagenhofer, A. (1999). Financial information on the Internet: a survey of the homepages of Austrian companies. The European Accounting Review, 8(2), 383-395.

Poon, P. L., Li, D., Yu, Y. T. (2003). Internet Financial Reporting. Information Systems Audit and Control Association, 1.

Pratt, L. (1996). Annual reports: in transition. CA Magazine, December, 13-14.

Rozhan, A. D. (2015). Transformation of Agricultural Sector in Malaysia Through Agricultural Policy. FFTC Agricultural Policy Platform (FFTC-AP). https://ap.fftc.org.tw/article/818

Samaha, K., Dahawy, K., Abdel-Meguid, A., and Abdallah, S. (2012). Propensity and comprehensiveness of corporate internet reporting in Egypt. International Journal of Accounting and Information Management, 20(2), 142-170.

Sia, C., Brahmana, R., Memarista, G. (2018). Corporate Internet Reporting and Firm Performance: Evidence from Malaysia. Contemporary Economics, 12(2), 153-164.

Verrecchia, R. E. (1983). Discretionary Disclosure. Journal of Accounting and Economics, 5, 179-194.

Wallace, R. S. O. (1988). Intranational and International Consensus on the Importance of Disclosure Items in Financial Reports: A Nigerian Case Study. British Accounting Review, 20 (3), 223-265. 
INTERNATIONAL JOURNAL OF ACADEMIC RESEARCH IN BUSINESS AND SOCIAL SCIENCES Vol. 10, No. 11, 2020, E-ISSN: $2222-6990$ @ 2020 HRMARS

Wallace, R. S. O., and Naser, K. (1995). Firm-Specific Determinants of the Comprehensiveness of mandatory Disclosure in the Corporate Annual Reports of Firms Listed on the Stock Exchange of Hong Kong. Journal of Accounting and Public Policy, 14, 311-368. 